\title{
AOS VINTE ESTADOS DO BRASIL E AO ACRE TAMBÉM
}

\author{
João Fabio Bittencourt \\ jotafabinho@gmail.com \\ Vera Chalmers \\ verachalmers@uol.com.br
}

O jornalista e crítico literário Brito Broca (1903 - 1961), em um artigo sobre o movimento modernista (A Gazeta, 6 set. 1958), noticiou que Peregrino Júnior $(1898$ - 1983) havia organizado, no livro O Movimento Modernista ([1954]), uma série de entrevistas com importantes escritores da década de 1920, nas quais discutia os rumos da arte brasileira após a Semana de Arte Moderna de 1922. Entretanto, Brito Broca equivocouse quanto à natureza da obra, que é fruto de algumas palestras que Peregrino Júnior ministrou no Chile, na Argentina, no Uruguai e no México, fazendo um balanço do movimento modernista no Brasil.

Todavia, é com o equívoco de Brito Broca que encontramos pistas do paradeiro destas entrevistas. Ao consultar O Movimento Modernista, nos deparamos com a seguinte declaração:

Espectador, ardente "torcedor" [...] e escriba. Jornalista militante [...] noticiei com probidade e simpatia todos os episódios do movimento comentando-o com isenção, entrevistei todos os seus líderes numa série de entrevistas que publiquei no O Jornal, ouvi Graça Aranha, Paulo Prado, Mário de Andrade, Ronald de Carvalho, Manuel Bandeira, Aníbal Machado, Álvaro Moreira, Carlos Drummond de Andrade [...] entre outros, nessas entrevistas - que Aníbal Machado sugeriu que fossem reunidas em livro - esses líderes 
definiram, cada um do seu ângulo pessoal, a significação, a importância e os rumos do Modernismo (PEREGRINO JÚNIOR, [1954], p. 4).

Encontrado o inquérito literário, averiguamos que, além de ser uma série de declarações colhidas no "calor do momento" em que se discutiam os rumos da arte após a Semana de Arte Moderna de 1922, também é o documento de que cada entrevistado, ao seu modo, empenhava-se por definir os parâmetros da sua arte e da arte contemporânea. As ideias estavam em efervescência e foi justamente neste sentido que Peregrino Júnior, na introdução à primeira entrevista com os modernistas de primeira hora, expôs as diversas inquietações que pairavam sobre as letras brasileiras.

Devia ser interessante ouvir, sobre o movimento moderno, essas individualidades contagiosas. Essa e outras. Que pensariam os "modernos" sobre a atualidade brasileira? Como explicariam eles o movimento moderno? Como justificariam eles as suas ideias? E como justificariam as suas divergências? Como definiriam eles a arte brasileira? O espírito moderno? As grandes ânsias e as grandes inquietações do momento em que vivemos? E os outros - os da "outra banda", também, não poderiam acaso dizer-nos coisas graves e curiosas? (O Jornal, 31 out. 1926).

Ao apontar que o espírito moderno estava preenchido por grandes ânsias e inquietações naquele momento e a solução talvez estivesse nas ideias desses homens que participavam da "atualidade mental do Brasil" (O Jornal, 31 out. 1926), o autor nos entregava um importante documento da época modernista.

Como foi dito acima, as entrevistas não foram publicadas em livro e é apenas uma parte da série formada por elas que foi coletada e organizada para este número da revista Remate de Males como documentos do Modernismo brasileiro'. Os textos são um inquérito literário elaborado e executado por Peregrino Júnior entre os anos de 1926 e 1927, quando era jornalista do periódico 0 Jornal, com exceção das entrevistas: "Como pensam e sentem os homens moços do Brasil”, concedida por Mário de Andrade a Jaime de Barros e publicada em julho de 1926 no diário carioca O Paiz, e "A pintura moderna vista por uma artista moderníssima", de Tarsila do Amaral e Oswald de Andrade, publicada sem assinatura de jornalista em agosto de 1926 em O Jornal, aqui incluídas porque também

1. Os textos foram colhidos por iniciativa de João Fabio Bittencourt sob a supervisão de Vera Maria Chalmers. 
integram e corroboram a inquietação daquela época, manifestada por Peregrino Júnior e seus entrevistados ${ }^{2}$.

\section{COMO PENSAM E SENTEM OS HOMENS MOÇOS DO BRASIL}

Mário de Andrade é um dos guias mais bizarros do movimento modernista.

A sua influência, segundo uns, está-se caracterizando de maneira perigosa, porque os seus adeptos procuram imitar, com uma perfeição admirável, os seus menores defeitos.

Para outros, porém, é útil o esforço que vem desenvolvendo para criar novos meios expressionais, fundando uma linguagem que seja psicologicamente nossa, estilizada por uma cultura resultante do conhecimento e da compreensão do meio brasileiro.

Mas a sua tentativa, devido em parte aos processos que emprega e à prevenção que os mesmos despertam, é frequentemente mal interpretada e incompreendida. Além disso, levanta dúvidas muito sérias quanto ao seu valor estético. Porque somos um "povo mocinho" deveremos realmente falar como crianças, ou ensinar as crianças a falar?

Parece que temos caminhado bastante, apesar de mocinhos, para regressar à primeira infância. Esse avanço, quanto à formação de uma língua nacional, de forma e ritmo diferentes da portuguesa, é justamente uma das mais gloriosas vitórias do movimento modernista. Mário Andrade contribuiu bastante para ela com a sua maneira audaciosa e bizarra de escrever. Os estilos atravessados, que obrigam o cérebro a verdadeiras corridas de obstáculos, são hoje ridículos. Caminha-se para uma maneira cada vez mais nossa de escrever. Maneira simples, natural, corrente, com um ritmo alegre em que as ideias se exercitam ao ar livre. O homem moderno não tem tempo a perder e precisa entrar logo no assunto a toda a velocidade. Aquela imagem do cavalo aplicada ao estilo é já agora uma bobagem. É dos tempos das carruagens. Sofremos horrivelmente da ânsia de explicar as coisas rapidamente e escrever, com os processos mecânicos de que dispomos, tornou-se um suplício. A pena marcha muitos quilômetros atrás do pensamento e a máquina diminui pouco

2. Nota dos organizadores: na transcrição dos textos, atualizou-se a ortografia do português e dos nomes próprios conforme previsto no Novo Acordo Ortográfico da Língua Portuguesa, mas foi mantida a pontuação original. Os títulos dos periódicos, os títulos de obras citadas no corpo das entrevistas e os termos estrangeiros foram mantidos na grafia original. Os erros tipográficos, do original, foram corrigidos. 
esse atraso. Tudo precisa ser rápido, instantâneo, vertiginoso. É por isso que muita gente não compreende e recusa compreender o movimento moderno. Falta de velocidade mental. Não compreendem que se voe em aeroplanos. Falta de segurança, perigos, síncopes, vertigens, desastres. É mais seguro andar a pé. O estilo destes, anda de muletas. É horrível lêlos, ouvi-los, suportá-los. Não têm velocidade, para agradá-los, é preciso andar devagar. O melhor é deixá-los para trás.

Mário de Andrade, como se vai ver em sua entrevista, diverte-se, por vezes, com novas formas de humorismo. Principia brincando e acaba sério, porque para ele brincadeira e trabalho "são igualmente nobres, desde que sejam vitais". Mas creio que lucraríamos muito mais se levasse as coisas mais a sério, pelo menos de agora em diante. Já se destruiu muito e é preciso construir alguma coisa.

A última parte de sua entrevista revela como ele vê claro o problema brasileiro, quando o encara através de sua grande cultura. A pândega pode trazer dúvidas sobre a sinceridade.

\section{Modernismo e verbo ser}

Consideremos primeiro o verbo ser. Que é ser? É ter uma realidade eficiente e relacional. Explico-me:

"Fui andando prum caminho

O capim cortou meu pé”... etc.

Pois, quando sucedeu isso, dei um pulinho de dor e falei: "Diabo de capim!". Por que falei dessa maneira? Porque o capim "é”. Foi eficiente e funcionou. Bem sei que a função dele é mais propriamente servir de comida para os marruás; isso não impede que, no caso da cantiga, tenha sido a de cortar meu pé. Aconteceu que tive uma dor danada e sai manquejando. O capim funcionou, teve uma realidade eficiente. Porém, isso não basta. Carece que essa função se relacione com as coisas. O capim "é" porque se relaciona com isto, com aquilo e, sobretudo, comigo, pela minha vista, pelo meu tato e, infelizmente, pelo pé. Ora, na escala das coisas que "são", o homem separa-se do resto por "ser" racional. Ele tem, por isso, um despropósito de determinações inteligentes que o mundo irracional não tem. Entre ser humanamente e ser irracionalmente mora uma diferença que vai como da baía de Guanabara para o pinheiro do Paraná. Para o mundo irracional, "ser", em última análise, consiste num "se deixar ser". As itás, os guarantãs e as antas deixam-se ser. Entidades vivas ou mortas, todas elas são coisas nesse sentido, que não podem dar, para si mesmas, destinos discricionários. O tamanduá não pode ofenderse se falo que ele é coisa, porém, já viram ofensa mais desprezadora do 
que afirmar: fulano é um coisa? Não tem, não.

Pois para que o homem não seja um coisa tem de refletir sobre como exercerá o seu verbo ser. O homem é uma entidade racional social. Pela racionalidade individualiza-se. Pela sociabilidade, humaniza-se. Quanto indivíduo, funciona em relação à própria finalidade, e como humano, em relação à finalidade social. Para isso, rege-se pelas ideias grandes do Bem, da Verdade, do Belo, da Humanidade, da Pátria e da Família.

Ser modernista significa ter uma realidade eficiente em relação à atualidade, regendo-se pelas grandes ideias universais.

Puro ovo do Colombo, como se vê. Dir-me-ão que isso é tão antigo como Platão e Aristóteles... Isso prova só uma coisa: que o modernismo é tradicional e tem função histórica antiquíssima. Tem.

\section{Nós queremos Deus}

Ser modernista é ser atual. Bastava dizer moderno. Emprega-se a palavra modernista para que a tendência e os representantes dela se distingam dos tipos vivos e, portanto, modernos (no sentido histórico da palavra), mas que funcionam, porém, negativamente em relação à atualidade, enfim: as coisas, os que "não são", os passadistas. Tão passadistas e tão não-seres que nem sequer funcionam como tradicionais, porque não tradicionalizam o passado, em vez, o repetem.

Toda a gente está esperando que eu fale de arte. Vamos a ver, pois, o indivíduo que escolhe o Belo para funcionar na atualidade. A civilização cristã salientou o indivíduo, fazendo do exame de consciência uma realidade prática. Foi, por isso, uma grande idade romântica, em que o indivíduo funcionou por demais em relação a si mesmo. Em oposição ao homem, inconscientemente social da antiguidade, Cristo salientou a eficiência do indivíduo. Mesmo a revivescência da Grécia, que provocou o Renascimento, só serviu para exacerbar, pela crítica livre, o individualismo inerente da civilização cristã. A influência desse individualismo funcional do cristianismo manifestou-se principalmente nas artes, e teve o seu clímax de exasperação com o século XIX, provocando o romantismoescola, a arte pela arte, e outros requififes pavorosos. Porém, tudo isso está deveras morrendo e a civilização cristã parece que está acabando sem que isso prejudique em nada a entidade divina de Cristo, é lógico. Ao contrário, parece-me que nunca a ideia de Deus preocupou tanto os artistas como agora. Os diretores da revista modernista Esthetica, do Rio, faz pouco tempo, afirmavam, num artigo lindo: "Nós queremos Deus".

Em resposta a carta dirigida a Paulo Claudel, pelos suprarrealistas, o documento mais doloroso de desespero humano que já li. Drieu 
la Rochelle lembrava a esses moços desinfelizes que ele[s] se tinham esquecido de Deus. Quando Le Dantec morreu, um crítico francês falava que desaparecera o último ateu. Não é bem verdade: ainda tem materialistas... no Brasil, coitados!...

Voltando ao assunto: hoje, o artista verdadeiro funciona de novo em relação à Humanidade, em vez de funcionar em relação a si mesmo. O som, a palavra, a cor, o volume, considerados como valores sensitivos universais é que deram origem a quase todas as tendências modernistas de Arte. Tendências indecisas, primitivas, turtuveantes [sic] ainda, com que se organizará uma Arte mais social e menos individual. Arte que corresponderá, quando crescer e se estabilizar, à civilização nova que está surgindo, que a gente não sabe ainda qual é, que não tem nome.

De que maneira nós, brasileiros, poderemos ser modernistas? Se funcionarmos em relação a nossa atualidade humana. E agora vejam, rapazes, como estamos funcionando:

O modernismo brasileiro (levianamente chamado de futurismo, no começo) não é imitação de escola francesa ou italiana; é uma incorporação do Brasil às tendências renovadoras universais. Que são universais, provei na minha Escrava que não é Isaura, citando propositalmente gente de toda a parte. Durante o romantismo já tínhamos sido universais, pois correspondíamos à tendência universal. Depois (e sempre em atraso!) fomos macacos do Jardim Zoológico de Paris, como já o fôramos no século XVIII, e mais desculpavelmente [sic], em relação a Portugal. Parnasianismo, realismo, simbolismo, tudo de imitação e tudo atrasado. Desde 1918, no mínimo, um grupo de artistas de São Paulo andava de mãos dadas com a atualidade artística universal. Esse modernismo generalizouse com rapidez. Hoje tem grupos no Rio, em Minas, em Pernambuco e representantes por todos os Estados da nossa terra. O atraso acabou-se. A imitação também, porque, fazer a mesma coisa ao mesmo tempo, não é macaquear: é concordar, seja ocasional, seja refletidamente. Eis como funcionamos em relação à atualidade.

\section{A moléstia de Nabuco}

E eis como funcionamos em relação à Humanidade: primeiro, convenhamos numa coisa: o modernismo europeu, depois de muita bulha e alguns descobrimentos técnicos apreciáveis, está se debatendo numa perplexidade que faz dó. Ou caíram num diletantismo infecundo, que nem os dadaístas, os cubistas, o grupo da "Sturm", os futuristas ou os mais sérios, querendo ter uma realidade funcional humana, meteramse num universalismo idealista songa-monga, sem nenhuma eficiência 
prática (isso quando não falam na tal de República europeia, que viria tornar ainda mais desequilibrado o desequilíbrio das nações), ou caíram num nacionalismo agressivo e reivindicador, soberanamente desumano e antissocial.

Isso para nós não sucedeu porque não tínhamos atrás a herança guaçu [sic] de uma civilização se esfacelando, caindo de velha e de uso. E o modernismo brasileiro pôs-se francamente a resolver o problema da realidade brasileira. É dessa forma que funciona para engrandecer a Humanidade. Não se trata de ser nacionalista, vejam bem. Não reivindicamos nada para o Brasil, a não ser o direito de manifestar a sua contingência humana de povo plasmado pelos ideais que lhe vêm do caráter psicológico, organizado pelas circunstâncias de mestiçagem raciais, de terra, de clima e de momento. Não somos nacionalistas. Contentamo-nos de ser brasileiros. E isto é realmente novíssimo num povo que sofre cronicamente da moléstia de Nabuco: nostalgia pela Europa e pelas tradições europeias. E que, quando reage, cai imediatamente no regionalismo, que torna a Pátria exótica e a esfacela sem precisão.

\section{É preciso viver e sentir como brasileiro}

Em todo o caso, o regionalismo é útil, porque concorre para a discriminação dos caracteres psicológicos gerais da nossa gente. Somos um povo mocinho, sem caracteres perfeitamente estabelecidos e com línguas artísticas importadas. Portanto, ainda sem meios nacionais de expressão. É na solução desses problemas que se lançou destemidamente o modernismo brasileiro. Temos de criar uma realidade nossa e uma expressão nossa que condigam com a nossa raça e a nossa terra. Então, uns puseram-se a dar à língua falada pela nossa gente uma estilização culta que não tem nada que ver com as regras gramaticais da língua portuguesa de Portugal. Outros, na pintura, na escultura e na música, fazem a mesma coisa. Sem, no entanto, esquecer nunca os ideais universais modernistas. E todos, com unanimidade bonita, querem viver, querem sentir e artefazer [sic] com[o] um só brasileiro o possa praticar na Terra. Se sentirmos e praticarmos como portugueses ou italianos, a Humanidade não aproveitará nada porque italianos e portugas já ela tem suficientemente e a engrandeceram. Porém, o dia em que o brasileiro for uma realidade prática e artística efetiva a Humanidade enriquecer-se-á com uma expressão nova de si mesma.

Eis como estamos funcionando como modernistas e brasileiros. Dentro da pândega, como dentro da seriedade, é indiferente, porque 
tanto a brincadeira como o trabalho são igualmente nobres, desde que sejam vitais.

Jaime de Barros.

O Paiz, Rio de Janeiro, o2 de julho de 1926, p. 1.

\section{A PINTURA MODERNA VISTA POR UMA ARTISTA MODERNÍSSIMA}

Tarsila do Amaral, de passagem pelo Rio, fala a $O$ Jornal

Tarsila do Amaral, que vem obtendo em Paris um sucesso extraordinário com a exibição de suas telas, sucesso que até aqui repercutiu através dos jornais franceses, esteve domingo no Rio de passagem para Santos. Passageira do Lutetia, desembarcou no sábado à tarde e, no dia seguinte, às primeiras horas da noite, prosseguiria viagem, não tendo tido tempo, assim, senão para receber os cumprimentos dos amigos e fazer um passeio rápido pela cidade. Foi no palacete do Sr. Geraldo Rocha, nos [ilegível] de Santa Alexandrina, que lhe achamos. A encantadora artista, solicitada pelo O Jornal, marcara a entrevista para as 11 horas de domingo. A essa hora, pontualmente, lá estávamos. Tarsila do Amaral, avisada da nossa presença, vem imediatamente ao nosso encontro, sorridente e amável, e, depois de apresentar-nos a seu noivo, o escritor Oswald de Andrade, senta-se e começa a falar das suas impressões de viagem, de Paris e seus artistas prediletos e conta-nos, então, que estivera, sábado à noite, no teatro Rialto, assistindo à representação da companhia preta.

- Gostei bastante do espetáculo e, especialmente, do trabalho desembaraçado das negras - acrescenta Tarsila - Apenas achei detestável a intromissão, em companhia tão tipicamente nacional de um artista de cor com o nome abominável de De Chocolat. Não seria muito mais interessante se não houvesse essa nota estrangeira comprometendo o cunho característico da "troupe"?

Muda-se do assunto. O Sr. Oswald de Andrade refere-se ao sucesso alcançado por Tarsila em Paris e, a propósito, mostra a reprodução em gravura de um jornal carioca, de um quadro seu.

A palestra encaminha-se, então, para a sua arte esquisita e original, toda feita de audácias e arrojos de composição e colorido. Intencionalmente lembramos à artista que esta não era a primitiva feição de seu pincel.

- Não me é difícil explicar, entretanto - respondeu ela prontamente e com vivacidade - a transição que a minha arte sofreu nestes últimos anos, ao contato dos mestres franceses e da pintura 
moderna e triunfante. Antes, essa transição é tudo quanto há de mais explicável. A pintura acadêmica, que eu comecei fazendo, nunca satisfez o meu temperamento irrequieto, que, ao contrário, se sentia tolhido em seus surtos mais espontâneos por uma série de regrinhas e preconceitos estéticos verdadeiramente humilhantes. Foi assim que me deixei seduzir pela escola moderna. Devo confessar, entretanto, que a princípio me pareceu facílimo pintar pelos novos processos. Ignorante que era da técnica da nova escola, acreditei também que um quadro cubista fosse um conjunto de tons coloridos desvairadamente dispostos.

Fiz alguns assim. Mostrando-os, depois, porém, a alguns conhecedores, compreendi que nada significavam e aprendi que o cubismo não era, como eu julgava, uma escola desorientada e maluca, na qual as cores e os traços não tinham significação real e sensível. Mais tarde, em Paris, passando repentinamente pelas galerias de arte, tive ocasião de admirar com maior cuidado e mais propício estado de espírito alguns quadros dos mestres franceses do momento. Comecei, a esse tempo, a sentir que ao cubismo melhor se adaptava o meu temperamento e que, nele, maior liberdade teria o meu espírito insatisfeito. Penetrando afinal o segredo compreendendo a beleza daquelas formas originais, logo me deixei empolgar e me dediquei ao estudo da nova escola. Passei a frequentar o curso do prof. Loti com assiduidade e aplicação. Loti, que é um grande artista, é um pintor cujos processos vacilam entre o academicismo clássico e o cubismo atual. Eu, por assim dizer, um espírito de conciliação entre o passado e as tendências modernas, colocado naquele justo meio-termo que é o segredo da harmonia do gesto francês. Tive depois outros mestres.

Identificada enfim com o cubismo, ainda aí, porém, o meu espírito não estacionou. Comecei a desejar criar uma arte mais pessoal e, desse modo, entrei a aperfeiçoar os processos aprendidos, torcendo-os a meu jeito e de acordo com o meu temperamento. Esse é o motivo por que os mestres do cubismo talvez não me julguem um elemento muito fiel à escola...

- Tarsila não é, como se tem dito e insistentemente repetido intervém o Sr. Oswald de Andrade - uma artista futurista. O futurismo é uma escola regional italiana que passou já, embora subsista ainda o seu chefe, que é Marinetti. No Brasil chama-se futurista a tudo que se afasta dos modelos clássicos. É uma denominação imprópria, entretanto.

- Realmente - continua Tarsila do Amaral - o futurismo é uma escola regional italiana que já passou. De resto, o movimento modernista da Itália me parece artificioso e falso. E explica-se: o italiano sofre a influência decisiva de uma pesadíssima tradição que não lhe permite 
se libertar um momento sequer, para livremente pensar e imaginar. O futurismo não consiste apenas na forma livre e original. Pode-se ser futurista num soneto, como se pode ser detestavelmente passadista em versos soltos, sem rima nem metro. Essa é a razão por que entendo que o centro de irradiação do espírito moderno está em Paris. De Paris partiu sempre a orientação espiritual do mundo. Ainda agora não perdeu a França sua hegemonia. Ao contrário, conserva-a ainda e brilhantemente. $\mathrm{O}$ sucesso do momento pertence incontestavelmente aos modernos e os preços a que atingem os seus trabalhos são bastante significativos. Algumas dessas telas são vendidas a 200 e até 300 mil francos, o que prova, sem dúvida, que já agora não são adquiridos só pelos colecionadores de extravagâncias e curiosidades. 300 mil francos por um quadro só dá quem de fato o compreende e aprecia devidamente. Engana-se quem julga, por incapacidade de compreensão, que uma tela cubista não representa nada. Também já tive essa incapacidade e, por isso, posso usar dessa linguagem sincera e, quiçá, rude. Representa tudo o que o artista sente e quis transmitir. Eu, por exemplo, antes de iniciar um trabalho, longamente, medito, imaginando os seus mil detalhes. Ninguém pode calcular o que me custam, em esforço, os quadros que faço. Ainda há pouco Oswald mostrou a gravura de um quadro meu, reproduzida num matutino do Rio. Nem a propósito. Aquelas figuras que ali se veem, eu concebi de uma candura de feições que, para reproduzir na tela, tive de lutar muito e muito me esforçar. Quem o olha com olhos profanos vê apenas uns bonecos diferentes dos homens que está habituado a ver; quem o examinar detidamente, porém, sentirá a emoção estética que sugere e compreenderá a dificuldade que a artista venceu. A escola moderna não é, portanto, uma coisa desordenada e sem métodos. Ela tem também os seus processos próprios. Apenas esses processos são muito mais amplos, permitindo aos artistas maior liberdade de ação.

Tarsila do Amaral fez uma pausa. O Sr. Oswald de Andrade comentou alguns quadros do "Salon", que o mesmo jornal já mencionado reproduz, achando-os defeituosos e inexpressivos. Acusa os irmãos Bernardelli dois monstros artísticos, segundo expressão sua - de serem nefastos à arte nacional e de terem prejudicado a espontaneidade e originalidade de várias gerações de artistas brasileiros.

Concluindo a nossa entrevista, perguntamos a Tarsila do Amaral se pretende expor no Brasil.

-Não sei ainda. Talvez. Em todo caso, não trouxe os meus quadros pintados em Paris. Os que não vendi na exposição, entreguei a um inglês para colocá-los em galerias diversas.

O Jornal, Rio de Janeiro, 17 de agosto de 1926, p. 02. 


\section{UMA HORA COM O SR. RONALD DE CARVALHO}

As questões de ordem estética nunca apaixonaram tanto os espíritos, no Brasil, como hoje. É unânime o interesse que atualmente despertam, entre nós, as agitações literárias ou artísticas. Prova disto foi, sem dúvida, o surpreendente alvoroço que no Rio e em São Paulo causaram, ainda não há muito, as famigeradas conferências do Sr. Marinetti. E não há memória, no Brasil, de um movimento intelectual que tivesse jamais despertado tão intensos entusiasmos como esse chamado "movimento moderno", que o Sr. Graça Aranha inaugurou com a sua conferência de junho de 1924. Pode dizer-se que nunca houve, nestas plácidas terras rotineiras, uma luta espiritual tão significativa, tão viva, tão brilhante, como essa, que ainda nos se apaixona e agita os espíritos.

Evidentemente as ideias que, há dois anos, o Sr. Graça Aranha teve a imprevista coragem de proclamar e defender dentro da própria Academia, despertaram no nosso meio um interesse excepcional. Além de sacudirem os nervos gastos da Academia, agitaram todas as inteligências do país. Chegaram, mesmo, a interessar a opinião pública. E interessaram-na muito mais do que se podia prever.

Entretanto, apesar de dois anos já terem passado sobre as belas palavras iniciais do Sr. Graça Aranha, ainda se faz entre nós, em torno das ideias modernas, uma grande confusão. O momento atual é ainda de agitação. De agitação de luta. E de confusão também. Nem se pense, porém, que são apenas os "passadistas" que divergem. Mesmo entre os "modernos", há divergências sérias. Cada indivíduo é uma opinião. Isto prova que não há aqui o que se possa chamar uma - "escola”. Graças a Deus! Cocteau poderia repetir de nós o que disse dos avant-gardistes franceses: Il n'a pas de groupes esthétiques. Il y a des individus contagieux. Positivamente é o que há no Brasil: indivíduos contagiosos - Graça Aranha, Mário de Andrade, Ronald de Carvalho.

Devia ser interessante ouvir, sobre o movimento moderno, essas individualidades contagiosas. Essa e outras. Que pensariam os "modernos" sobre a atualidade brasileira? Como explicariam eles o movimento moderno? Como justificariam eles as suas ideias? E como justificariam as suas divergências? Como definiriam eles a arte brasileira? O espírito moderno? As grandes ânsias e as grandes inquietações do momento em que vivemos? E os outros — os da "outra banda", também, não poderiam acaso dizer-nos coisas graves e curiosas?

Deliberamos, por isto, ouvir sobre o momento literário e artístico do Brasil, não só os "leaders" das novas correntes estéticas, mas também os das antigas. Velhos e novos — sem distinção de credo estético - falar- 
nos-iam, todas as semanas, em uma hora de simples palestras, sobre a atualidade mental do Brasil.

Pedimos emprestado a Frederico Sepure a rubrica das suas entrevistas de Les Nouvelles Littéraires, e fomos procurar os nossos mais significativos escritores.

\section{No palacete da rua São Clemente}

O primeiro que ouvimos foi o Sr. Ronald de Carvalho. Fomos encontrá-lo uma tarde destas, na sua linda residência na rua São Clemente, no 409. O ilustre poeta de Toda a América recebeu-nos no seu gabinete de trabalho - uma sala ampla e iluminada, onde os livros, os quadros e os objetos de arte se dispõem numa sóbria elegância.

O Sr. Ronald de Carvalho é um nome que dispensa apresentações é um dos grandes nomes do Brasil de hoje. Quem acompanha a evolução mental do país, sabe muito bem o que significa este nome na atualidade brasileira. Inteligência das mais altas e mais claras da sua geração, o Sr. Ronald de Carvalho deu-nos algumas das obras mais belas de que pode orgulhar-se a nossa literatura. Da Luz Gloriosa aos Jogos Pueris - sem esquecer Poemas e Sonetos, Espelho de Ariel, Pequena história da literatura brasileira, Epigrammas irônicos e sentimentaes, Estudos Brasileiros e o grande poema Toda a América - a obra do Sr. Ronald de Carvalho é, toda ela, um documento de trabalho honesto, de entusiasmo sincero, de cultura e de inteligência. Espírito dinâmico, em evolução constante, a sua atividade descreve o espiral de uma ascensão permanente. Sem prejudicar a unidade da sua obra - que é toda marcada por um belo entusiasmo construtor - o Sr. Ronald de Carvalho tem sido diferente em cada livro. Nunca se repetiu! E aí reside talvez o segredo do poder de fascinação dessa sedutora individualidade, que é um dos espíritos de maior projeção do movimento moderno.

\section{A arte brasileira}

À nossa primeira pergunta, o Sr. Ronald de Carvalho respondeu:

- Os problemas que sua pergunta sugere são de tanta complexidade que, para resolvê-los, seria mister isolar a nossa própria consciência individual do tumulto brasileiro. Ninguém poderá dizer-lhe, com segurança, o que é ou o que será uma arte brasileira. Tudo mais será atrevimento de meninice livresca, atrevimento que se deve acolher sem intolerância, porque distrai como um salto mortal e não faz mal nenhum. Para responder a sua pergunta seria necessário um ponto de partida, 
uma base real que assentasse num complexo ético, social e político perfeitamente determinado, com todas as suas consequências lógicas. Temos uma soma de experiências muito parcial, nesse particular. Toda essa profunda ansiedade que o senhor observa na inteligência brasileira é um simples reflexo da luta com o indefinido, característica do espírito americano.

Indefinido é o conhecimento das terras que ocupamos, indefinidas são ainda, em grande parte, as fronteiras comuns, indefinido o caráter dos povos que se cruzaram neste continente, indefinida é a sua história, a gênese das raças e das civilizações primitivas astecas, incaicas, aymaras e maias e guaranis. Não conhecemos sequer a geo-história do nosso habitat, que somente agora, com as cartas minuciosas levantadas pela Comissão da Sociedade Geográfica Americana, nos vales do Peru e da Bolívia, começa apenas a desvendar-se. Veja o senhor, por exemplo, o que sucede com os monumentos mais celebrados da América pré-colombiana, como as pirâmides de Teutiuhacan e os templos de Tiahuanaco. Os milênios dos cálculos astronômicos de Posnansky se reduzem a centúrias nas conclusões de Imbelloni. O indefinido sempre. O que parecia matéria vencida, ontem, passa a constituir novamente, hoje, a questão aberta e litigiosa. O mongolismo de Humboldt, o autoctonismo de Simonin, de Briton ou de Kollmann vão chocar-se com o oceanismo de Rivet, de Imbelloni e de Palavecino, genialmente vislumbrado, aliás, pelo nosso Gonçalves Dias. Indefinido na terra, indefinido nas raças, indefinido nas línguas! Para esclarecer o assunto misterioso todas as provas foram tentadas, desde o processo de empirismo estético de Virchow até o da iso-hemaglutinação [sic] de Nutuall e Friedental. Acrescente a tudo isso a querela glotológica miúda, a enorme quantidade de glossários, desde os fantásticos de Basaldua, com o seu povo de Escalduns conquistadores, aos inesperados de Rivet e Palavecino. E não se afirme que tais problemas são exclusivamente científicos, dignos apenas de serem pesquisados no campo da especulação abstrata. Todos os povos do Novo Continente, mesmo aqueles que estão intimamente ligados pelo sangue às raças da Europa, comungam, em maior ou menor escala, das origens indoamericanas.

\section{Uma grande família sem brasões}

- "Somos, portanto, uma grande família sem brasões, continuou o Sr. Ronald de Carvalho. Gozamos o usufruto de riquezas desmedidas, sem título certo de propriedade. Herdamos uma espantosa fortuna sem saber de quem. Um dos males profundos que semelhante herança nos 
transmitiu foi justamente essa inquietação, essa instabilidade a que aludi, no início da nossa conversa. A história dos povos americanos, até a dos Estados Unidos, não oferece ainda uma lei de constância moral, política ou intelectual. Cada fenômeno traz um complexo de hipóteses nas suas causas produtoras. A mesma causa dentro do mesmo país, determina fenomenologia distinta. Conhece a obra de Frank Schoell, antigo professor da Universidade de Chicago, sobre o problema dos negros nos Estados Unidos? Pois bem, aí verá o senhor que a mesma causa, isto é, o contato do branco com o negro, dá origem a fenômenos sociais muito diferentes, quando se trata de um Estado como Nova York, ou de um Estado como a Geórgia. Ora, se isso se verifica em um país, onde o desenvolvimento da fortuna pública e particular facilitou grandemente uma larga e generosa comunhão de interesses entre todos os cidadãos da União, que diremos do Brasil, cuja civilização ainda está no litoral, à mercê, portanto, de influências estranhas e perturbadoras, de catalisações mais frequentes?"

\section{Por que será negra a nossa arte?}

- Dizer que a "nossa" arte deve ser negra, índia ou portuguesa, é o mesmo que a inculcar de grega ou etrusca. Por que será negra a nossa arte? Quem já determinou, com precisão, a dose de sangue negro que entrou na composição do mestiço brasileiro? As deformações que o negro introduziu em nosso léxico ou em nossa prosódia não bastam para lhe conceder foros de primazia na formação da nossa linguagem. O que a muita gente parece influência puramente étnica é simplesmente uma resultante mesológica, resultante que Ratzel e Vidal de La Blanche, nos seus quadros de Antropogeografia, estudaram admiravelmente. Muitas deformações na vocalização ou nos elementos consonantais correm por conta de sutilíssimos imponderáveis climáticos. Se o português do Brasil se distingue do de Portugal na fonologia, na morfologia e na sintaxe, por uma série de síncopes, epênteses, iotisações, nomes e regências diferentes, o mesmo acontece com o espanhol da Argentina, do México, do Peru e do Chile em relação ao da Espanha. Às vezes, como na supressão do " $\mathrm{r}$ " final dos tempos infinitivos, dá-se o mesmo fenômeno, aqui, onde há negros, e no Chile, onde eles não existem. Mas igual fenômeno se observa na França, na Itália, na Inglaterra, em todos os países do mundo, onde correm paralelas duas línguas, uma superior, que representa naturalmente uma tradição de vida social e intelectual, e outra vulgar, feita ao sabor das contingências, variável, oscilante, língua de cenáculos, de escolas, de ateliers, de agrupamentos passageiros, de esporte, de toda espécie de classes humanas que serve para enriquecer a outra, mas não substituí-la. 


\section{Um erro ingênuo}

- Fixar o padrão do negro, no estado primitivo em que este, geralmente, se encontra no Brasil, é um erro ingênuo. $O$ negro não mora em casa de latas velhas simplesmente porque é negro. Não é esse o grau máximo de civilização [a] que ele aspira. Quando um negro chega a ser Booker Washington ou Du Bois, mostra a capacidade superior, de cultura que pode atingir a sua raça. E, aqui, entramos em um outro problema do mais [sic] interesse para nós. O "Homo Afer", tal qual o "Homo Europaeus" é passível de classificações extremas, que oscilam entre índices muito baixos e índices muito elevados. $\mathrm{O}$ branco tirolês está para o branco saxão como o Boschimano para o Yoruba. Entre nós o estudo do negro é quase nulo. Apesar do trabalho de Nina Rodrigues e Perdigão Malheiro, nada ou quase nada conhecemos, com exatidão, acerca do problema das raças negras que vieram para o Brasil. Podemos conjecturar, como os indianistas do período romântico, tudo quanto quisermos em relação a eles. Faremos I-Juca Piramas pretos, substituindo a realidade pelo senso lírico. E será tudo. É curioso, entretanto, verificar que, nos Estados Unidos, a raça humilhada reage a cada momento, funda bancos e hospitais, lança revistas e jornais, custeia Universidades e desafia com heroísmo o destino melancólico herdado da escravidão. E ter-se-á perfeita noção da sua energia, quando se lê, em Souls of Black People, a exclamação de Burghardt Du Bois: "O problema do século XX é o problema da fronteira da cor".

\section{O nosso negrismo é livresco}

- Esse negrismo que o parisiense, com o seu Art Negre, inventou genialmente, é uma coisa compreensível na Europa, necessitada de espantos, mas livresca no Brasil. O negro é um dos elementos que contará, sem dúvida, a nossa arte, mas não pode ser a sua primordial substância, tal qual o índio e o branco europeu. Ficar adstrito a qualquer um desses elementos é acanhar o horizonte próprio. Se a civilização americana é uma soma de elementos díspares, e a arte é um epifenômeno da civilização, deve ela também ser uma soma dos elementos que se integram na sua casualidade.

\section{A missão do entusiasmo}

- Quem conhece a América intimamente, quem a viu e quem a analisou nas suas diversas correntes humanas, quem não a ajuda 
por juízo alheio, mas pelo juízo próprio e direto, não pode deixar de concluir que a exaltação e o entusiasmo estão na raiz da sua aventurosa existência social e política. O fundo melancólico das raças inferiores que aqui se caldearam com o europeu, exaspera-se, frequentemente, num misticismo doutrinário e combatente, em verdade, furioso. O mestiço que Euclides da Cunha viu transforma[r]-se no titã é o caudilho de Sarmiento, o campeador de Ricardo Palma, o cavaleiro de Oaxaca ou o do Texas. A América, como fenômeno humano, com índice da cultura, não é o peão miserável de Cuzco ou de Quito, assentada à soleira das casas de adobe mascando coca, nem o preto da viola indolente, nem o pachola carnavalesco. Pois todos esses milhões de libras, que o engenho do homem produz aqui, essas terras que se lavram, essas cidades que se levantam, todo esse esforço é fruto de seres humilhados, envergonhados, abatidos? Tudo isso, toda essa conquista permanente, todo esse edifício de energia poderá ser feito sem entusiasmo?

Eis aí a minha primeira conclusão. A arte brasileira, como a arte americana, tem uma grande missão: a missão do entusiasmo. O senhor se lembra dos conselhos do W. James, nos seus Princípios de Psicologia? $\mathrm{O}$ senhor sabe que o entusiasmo é o corolário de uma boa higiene. $\mathrm{O}$ homem que trabalha é um criador espontâneo de entusiasmo, porque a sua sensibilidade e a sua inteligência se equilibram na continuidade da ação. Procuremos, portanto, fazer a propaganda do homem que trabalha, do homem que vence a realidade pela disciplina da ação, do homem que não tem tempo de se comparar aos outros, porque está sempre transmitindo a si mesmo uma lição de energia, portanto, de saúde. Articular que isso é uma atitude, nada adianta ao problema. Porque não será uma atitude, também, e atitude desconforme com tudo quanto nos está mostrando a realidade americana, a prepa[ra]ção da realidade e do monstruoso? O homem moderno é o avesso de tudo isso, é aquele chauffeur, de Kaiserling, limpo, forte, lúcido, rápido e sintético. O homem moderno não balbucia: ordena e comanda. Dirige, em suma.

\section{O curinga que atrapalha}

- Cocteau disse que a arte era um jogo de convenções variáveis. Cocteau repetiu, com a sua graça de galo brigão, as severidades da tese de Guyan. Não lhe parece que ainda somos jogadores pouco atirados? Não encontramos o nosso grande preconceito estético, mas cada um de nós tem o seu pequenino preconceito, espécie de curinga que entra para atrapalhar o jogo dos outros. Rio-me desse curinga, porque alguns o apresentam bem vestido e outros exibem um manipanso de tripas de 
palha. De ambos os lados há uma ilusão igual. Falo dos que têm boa fé. Os outros não me interessam.

\section{O quadro brasileiro}

Lidamos com um material informe e desmesurado, jogamos com todos os problemas de um povo que se está formando. Terras imensas despovoadas, conflitos de interesses econômicos entre vários dos grupos humanos que habitam os nossos Estados, instabilidade da fortuna pública, desconhecimento das exigências mais triviais da coletividade, eis o quadro em que se move o brasileiro.

\section{Ser moderno não é ser futurista nem esquecer o passado}

- Precisamos disciplinar a nossa inteligência pelo estudo direto do Brasil. O homem novo do Brasil quer viver a realidade do momento. Passou o tempo das intoxicações de teorismos abstratos. Ser moderno não é ser futurista nem esquecer o passado. Ninguém pode esquecer o passado. Repeti-lo, entretanto, seria fracionar artificialmente a realidade, que é contínua e indivisível. Ninguém pode voltar atrás, pelo simples desejo de voltar atrás. A história da arte registra recuos imprevisíveis, mas nesses recuos há determinantes invencíveis. Sob o ponto de vista estético, a civilização antiga foi a civilização do palácio e do templo, do aqueduto e do circo, a civilização da pedra. A civilização moderna é a civilização do aço e do ferro, do carvão e do petróleo, a civilização dos transportes e da máquina. Portanto, dois tipos diversos de civilização. Civilização espacial, civilização temporal.

\section{O homem que inventou a máquina}

- O homem que inventou a máquina não tem a mentalidade do seu antepassado. Aquele faz do tempo uma ideia de poupança, este uma ideia de desperdício. A máquina, baseada na economia da força, é uma coordenação de planos, que conjugam para certas resistências e determinados movimentos. É uma síntese de energia. Cada uma de suas peças existe em função das demais. Ela aproveita a matéria-prima, e a obra que produz é o resultado de um rendimento exato, calculado e previsto, sem gastos inúteis. A imaginação criadora do artista reflete, como é natural, todas essas aquisições da experiência humana. Funciona como verdadeira máquina, reduz a natureza a um esquema e, pela deformação da matéria-prima que lhe fornece a realidade, produz a obra de arte. Se 
o senhor quiser um exemplo do que lhe afirmo, basta considerar a obra de Balzac e a obra de Proust. Balzac é um descritivo, um homem que precisa de largos planos de superfície, um realizador no espaço. Proust é um homem para quem o espaço, propriamente, não existe. Os seus planos são verticais e sucessivos ora tomam a direção da profundeza, ora da altitude. É um realizador no tempo.

\section{Artista moderno é senhor do seu ritmo}

- O homem livre moderno, ao contrário do escravo e do servo do mundo greco-romano e medieval, não pode perder tempo com a ciência minuciosa do pormenor decorativo. É um inimigo forçado daqueles gastos inúteis, de que lhe falei. $\mathrm{O}$ padrão econômico das sociedades modernas é o maior nivelador possível. A vida moderna tende para o standard, para a normalização cada vez mais crescente. O operário é igual ao arquiteto, e ambos são iguais ao proprietário que os paga e está sujeito às mesmas leis e aos mesmos deveres. O poeta que hoje não é bufão do senhor feudal ou fâmulo da sua mesnada, nem o pintor é lacaio do rei. O artista moderno, pois, libertado do cânon social e político do passado, é senhor do seu ritmo. Isso, entretanto, não quer dizer que ele deva desprezar a disciplina de experiência que lhe foi herdada. Seria pueril afirmá-lo. Basta considerar, por exemplo, certos modelos de arte moderna para ver como futuristas, cubistas, expressionistas e modernistas sem credo dogmático estão, por outros motivos, servindo-se de alguns processos usados antes até da idade clássica. Refiro-me aos esquemas, às simplificações ideográficas, empregadas não só na estatuária e na pintura, mas na própria escrita moderna. Entre os kuros do VI século a. C., com a sua rijeza geométrica, e uma escultura de Mestrovic, Brancusi ou Archipenko, há pouca diferença de processo, embora o sentimento fundamental seja inteiramente outro.

\section{A arte moderna do "Assumto", do motivo da cópia}

- O artista do século XX volta, pelo sóbrio idealismo da sua técnica, ao sincretismo dos primitivos e ao sintetismo do século VI a. C. e do século XIII, em França e Itália. Entre o Cristo, de Amieno, que o Sr. W. Deonna comparou a um deus da escola de Phidias, e uma cabeça de Mestrovic já não há consideráveis distâncias. A escultura contemporânea retomou a lei de frontalidade, quebrada por Mirão, e continuada na Idade Média pelos santeiros de Chartres e da Ilha de França. 
O realismo predominante no século XIX foi substituído pelo sentimento lírico e ideal das formas e dos volumes. $\mathrm{O}$ artista moderno é um deformador. Ele procura um equilíbrio geométrico, fora da natureza, além da realidade, o que aparenta profundamente aos obreiros medievais, aos negros de Benin e do Congo, aos artistas do Egito e da Pérsia, e veja o senhor até onde vai o modernismo, aos gravadores das cavernas da Altamira e da Dordonha. A obra de Luschan, Altertümer Von Benin, depara-nos vários testemunhos desse realismo intelectual, tão comum entre os artistas paleolíticos. Há, nas cabeças de madeira ou de argila das coleções de Rushmore, de Luschan e Frobenius, um aspecto de semelhança familiar com os documentos estéticos da Idade de Rena e do Cubismo. A simplicidade da composição se restringe às fortes superfícies planas, aos ângulos ásperos, aos puros contrastes lineares. Como nos desenhos digitais de Gargas, o artista se diverte com o jacto contínuo das linhas, preferindo, contudo, ao movimento das espirais, ao mole desdobramento das curvas longas e preguiçosas, os planos retos voluntariosos. Compare, por exemplo, a máscara no 12, do álbum de K. Einstein, à de no 15 da recente coletânea de Roberto Montenegro. Ambas, tanto a de Benin quanto a dos maias, são documentos que provam as remotas origens do cubismo.

Aquela ciência do pormenor decorativo, que tomou todo o período helenístico e serviu de base aos artistas do Renascimento, está inteiramente abandonada. Os homens daquelas duas épocas estavam dominados, como viu Spengler com toda a razão, "pela fórmula teórica da vontade estética". A arte moderna libertou-se do "assunto", do "motivo", da cópia, em suma. O seu único objetivo é comover pela exaltação lírica dos ritmos e das formas.

\section{O sintetismo contemporâneo}

— Essa é, aliás, uma das consequências do sintetismo contemporâneo. Levado, talvez, pela observação de tais fatos, escreveu Lalo que l'incohérence des débuts dont ressemble du dehors à la complication organiseé qui termine tout évolution comme l'extrême analyse ressemble à l'extrême confusion. Ainsi, dans l'art, le premier et le dernier âge sont tous les deux, par rapport à ce qui précède et à ce qui suit, une complication et même une incohérence à certains égards. O "purismo" de Ozenfant e Jeanneret, descendentes diretos da experiência cubista de Picasso e Braque, revela, ao observador superficial, a incoerência a que se refere Lalo. A extrema simplicidade da matéria com que trabalham os puristas 
confunde-se com o profundo senso analítico das máscaras negras ou précolombianas.

Tanto quanto é lícito concluir, portanto, o que caracteriza a arte moderna é o horror ao acessório, ao indeterminado, ao trivialismo das reproduções fáceis. Essas reproduções fáceis, entretanto, não se limitam ao soneto parnasiano e ao vago musical dos simbolistas, mas também ao "pompeirismo" [sic] dos imitadores de Apollinaire ou de Aragon. Toda a criação estética de hoje está sujeita a uma grande lei de lirismo cerebral. O idealismo do século XX libertará o artista do realismo convencional que nos impôs até agora, o Quattrocento.

\section{Uma arte de força, uma arte criadora de entusiasmo}

Voltando ao Brasil, e para terminar, dir-lhe-ei que não compreendo, aqui, senão uma arte de força, uma arte criadora de entusiasmo, virgem e tônica. Uma arte que possa lembrar um pouco, ao homem de amanhã, que o pessimismo dos antropólogos, o pessimismo de Buckle, de Gobineau e de Lapouge a nosso respeito, não [influi] 3 mais no espírito dos homens de hoje. Uma arte que reflita a grande lei de que a civilização é uma conquista do homem sobre a natureza.

O Jornal, Rio de Janeiro, 31 de outubro 1926, 2ª secção, p. 4.

\section{UMA HORA COM O SR. RENATO DE ALMEIDA}

Ouvimos, desta vez, o Sr. Renato Almeida. O Sr. Renato Almeida é um espírito grave e reflexivo. As suas atitudes como as suas obras, denotam, além de apreciáveis qualidades de equilíbrio, uma bela e constante serenidade.

Tendo tomado parte na "Semana de arte moderna", de São Paulo, enfileirou-se, desde logo, entre os modernistas moderados. E a sua atuação, ao lado deles, tem sido leal, sincera, honesta e resoluta.

O Sr. Renato Almeida, que já publicou duas obras notáveis de crítica e pensamento - Fausto e Historia da Musica Brasileira, disse-nos, com franqueza e elegância a sua opinião sobre a atualidade brasileira.

3. Erro tipográfico: substituição do termo original "influía” por "influi". 


\section{O que procura o movimento moderno}

O movimento moderno, começou ele, cuja razão de ser, não se discute mais, procura hoje fixar as suas diretivas para uma criação brasileira. A pesquisa dos problemas nacionais empolga a inteligência nova do país, ansiosa por se libertar da imitação estéril, e é uma conquista audaz. À nossa geração, sobretudo, tem cabido investigar das [sic] forças formadoras da nacionalidade, através de um critério largo e elevado, que se banha de um universalismo construtor, e dessa verificação serão possíveis fortes realizações. É inegável que, à míngua de muitos elementos, se vão tirando conclusões apressadas, ou se forçam semelhanças, quando a demonstração histórica é falha, ou as resultantes das forças em jogo estão por se firmar. Daí o caráter de obra por fazer, que tem esse esforço, que se apresenta como uma larga contribuição de materiais. Portanto, não deixam de ser curiosas as ingênuas afirmativas de quantos mal suspeitam do problema e logo aparecem, felizes e sorridentes, com soluções prontas, perfeitas [,] acabadas e intransigentes. Nesse jogo arriscado, onde há tantos dados cujo valor desconhecemos, é perigoso contar com tais certezas, porquanto nem a nós caberá verificá-los. Ainda se está a armar a equação e já lhe querem descobrir as incógnitas.

\section{A formação brasileira}

- A primeira dificuldade está na história [da] ${ }^{4}$ terra, continuou o Sr. Renato Almeida, depois na do homem que veio povoá-la e se juntou com os que já a habitavam. E mais tarde outros vieram - negros, morenos e louros - misturaram-se, caldearam os sangues, importaram-se ideias e livros, livros e mais livros, roupas, costumes e modas. Trabalharam por conta própria e por imitação até que um dia, desse caos, começou a surgir uma consciência. Esta é que nos fascina e mal o suspeitamos já há afirmativas audazes e pretensiosas. De um espírito brasileiro, sabemos todos, porque o sentimos bem claramente, mas nem mesmo como se manifesta poderíamos dizer com segurança. Temos certeza dele, mesmo não o podendo demarcar.

\section{Uma terra de aluvião}

Após uma pausa, prosseguiu o autor do Fausto:

- Somos ainda uma terra de aluvião e há muito que solidificar. Pelos

4. Erro tipográfico: substituição do termo original “de" por “da”. 
oito milhões de quilômetros quadrados, que se distendem no país enorme, existem tantas espécies de gentes, tantas feições diversas, tantas vidas diferentes, que a própria unidade nacional é um mistério perturbador. Depois o tipo brasileiro, dos nordestinos audazes, resistentes e feios, aos sulistas de olhos azuis, cabelos louros e nomes arrevesados, que variação enorme! Filhos de quantos sangues se misturam todo dia para dar afinal um brasileiro legítimo? e a ação mesológica e tantos e tantos outros fatores convergentes? Evidentemente os homens que vieram nas caravelas, ou os negros caçados na África e enviados para o Brasil, não sentiram a terra, como os imigrantes que desembarcam nas nossas cidades e vão trabalhar em colônias agrícolas modernas e prósperas. A adaptação destes não se fará pelos mesmos processos e a natureza vencida tem o encanto da paisagem maravilhosa, enquanto a brava aterrorizava com os seus mil desafios e temores. Uns vieram trabalhar na terra virgem e bruta, outros vêm enchê-la de braços ativos para a riqueza. Mas trazem todos o seu sangue para o caldeamento. Depois os vários climas, o aspecto geográfico do país, os pontos de civilização e as influências espirituais e econômicas, tudo isso tem de ser levado em conta. Para que todos esses elementos e muitos outros, sejam computados, é necessário, antes de tudo, fixálos. Acentuando a dificuldade com que se nos apresenta o problema, cuja investigação será destino de longa porfia do nosso espírito, realço a imprescindível contribuição de todas as inteligências e sensibilidades, num estudo sincero e honesto, com espírito próprio e sem preconceitos, sobretudo os importados, o que equivaleria a rondarmos de novo em derredor da imitação.

\section{O trabalho da arte}

Fez uma pausa, e prosseguiu:

- Esse estudo não será certamente de fria análise apenas, simples esforço de erudição. Além disso - porque afastados da cultura não se fará nada de sólido e definitivo, tão somente improvisações — há o trabalho da arte. E será mesmo, mais do que tudo, obra dos artistas, como os grandes adivinhos de nosso destino e finalidade. Na poesia do Ronald, do Mário ou na música do Villa, por exemplo, quanto material para a revelação do Brasil! Não se discuta inutilmente se o ponto de vista do artista é todo Brasil, porque seria pueril a pretensão de quem quisesse, no nosso caos, fazer obra completa, mas aproveite-se o que cada qual nos tiver trazido de novo e surpreendente. Depois, que ridícula essa disputa que anda por aí para saber se a este ou àquele cabe o privilégio de estar certo, desta ou daquela banda, mais ou menos moderno. E o interessante 
é que muitos desses que animam tais discussões, nada fizeram ainda que lhes possa definir lugares. Louvam-se nas obras alheias à míngua de próprias...

\section{A atividade do espírito moderno}

E concluindo, afirmou ainda:

- Mas o que interessa é a atividade do espírito moderno, o ansiado desejo de produzir coisa nossa, é a poesia, a música, o pensamento, refletindo-se já sobre toda a vida nacional, que um dia se transformará a esse toque de energias novas. Há em tudo a vontade do Brasil e por isso eu creio fecundas as orientações modernas, mesmo as de que me afasto e combato, porque, neste momento, já lhe disse, não há contribuições que, de antemão, se possam saber inúteis. Aliás, as divergências são as mais fortes afirmações do movimento, cuja unidade está apenas em reconhecermos todos que é preciso criar uma obra brasileira. Graças a Deus cada um procura realizar essa aspiração a seu modo, chegando livremente a conclusões próprias, que poderão estar certas ou erradas, mas marca o grande esforço desta hora tumultuosa e magnífica. Pareceme que isto é o grande problema para o espírito moderno.

O Jornal, Rio de Janeiro, 28 de novembro 1926, 2ª secção, p. 5.

\section{UMA HORA COM O SR. PAULO PRADO}

Uma hora? Não. Cinco minutos. Ou talvez menos. O Sr. Paulo Prado foi absolutamente moderno [.] ${ }^{5}$ Século XX. Rapidíssimo. Conciso [.] ${ }^{6}$ Claro. Não demorou. Nem divagou. Disse com rapidez o seu pensamento claro e exato. E nem por isto a sua resposta ao nosso inquérito deixou de ser interessante. Foi interessante e completa. Disse o que desejávamos que ele dissesse.

Residindo o Sr. Paulo Prado em São Paulo, mandamos-lhe, há dias, uma carta, solicitando-lhe resposta ao nosso inquérito. Queríamos desse claro e forte escritor que nos deu a Paulística e que foi um dos fundadores do movimento moderno entre nós, uma palavra sobre a atualidade mental do Brasil.

5. Erro tipográfico: falta do ponto final.

6. Erro tipográfico: falta do ponto final. 
Os escritores que tínhamos ouvido, constantemente nos falavam de "espírito moderno", "futurismo", "arte brasileira", "novas diretrizes e características da nossa literatura" etc.

Ninguém melhor do que o Sr. Paulo Prado poderia falar-nos sobre essas coisas. Ele podia muito bem trazer alguma claridade à confusão do momento. A nossa carta pedia-lhe tudo isso. E o Sr. Paulo Prado, mal recebeu o nosso pedido, imediatamente nos mandou, com uma elegância cativante, a sua resposta, numa breve carta, incisiva e clara, que é uma das páginas mais harmoniosas e lúcidas que se têm escrito, entre nós, sobre atualidade brasileira. Uma entrevista epistolar.

Ei-la aqui:

A resposta do Sr. Paulo Prado.

Diz assim:

"São Paulo, 11 de dezembro.

Sr. Redator,

Tenho o prazer de acusar o recebimento de sua carta de 8, agradecendo as amáveis e imerecidas referências a minha pessoa.

O seu interessante inquérito, que já tem provocado tão brilhantes respostas, sugere questões difíceis de elucidar na rapidez de um artigo.

Espírito moderno, futurismo, arte brasileira, novas diretrizes e características da nossa literatura.

Para a discussão tranquila desses problemas faltam-nos certamente nesta ocasião o necessário sossego de espírito e de paixões. Outros cuidados falam mais alto do que as mais atraentes polêmicas artísticoliterárias. Todos nós o sentimos. Eu, pela minha parte, confesso conhecer três ou quatro casos de tirar o sono ao mais indolente patriotismo...

$\mathrm{O}$ seu inquérito, além disso, contém interrogações deveras embaraçosas. Conviria talvez começar por um glossário que explicasse a exata significação de certas expressões ou termos.

Espírito moderno... Não sei bem o que seja. Um amigo meu, erudito, afirma que o inventor do modernismo foi o célebre Luciano de Samosata, morto no ano de 192 da era cristã. A escola vem, pois, de longe. O melhor método de classificação é o que já foi sugerido, de proceder por negações ou exclusões. Tal escritor é modernista, este outro não é. Processo quase infalível. Evitando citações de nomes nossos, exemplifiquemos: Anatole France e d'Annunzio são passadistas, Guillaume Appolinaire, Blaise Cendrars e mesmo Baudelaire, que morreu há 60 anos, são "modernos". Por quê? Complicações. Nem um livro inteiro bastaria para esclarecê-las.

Há evidentemente no momento brasileiro um pequeno grupo de escritores de vanguarda, distanciados da massa gregária que se move com cinquenta anos de atraso e com exasperante lentidão. Serão 
perfeitamente "modernos" no minuto exato em que escrevo esta frase? Representam, apenas, o que poderemos chamar a época do aeroplano. Sucede a época do automóvel, em que apareceu o defunto futurismo. Depois do avião, porém, que nova modalidade já estará tomando, no seu incessante e vertiginoso ímpeto de renovação, o espírito humano? Os modernistas de hoje (os selecionados) vão se cristalizando em clássicos; outros surgirão, com surpresa e indignação nossa, para constituir a literatura de tout à l'heure. E assim o espírito moderno, como toda entidade viva, irá mudando de forma...

Quanto à arte brasileira, lembro-me - destacando três exceções magníficas - da resposta do genial Picasso a um questionário sobre arte negra: Arte brasileira? Connais pas.

Peço desculpas [pel]o apressado e descosido destas linhas despretensiosas, e creia-me

seu muito ad. ${ }^{\circ}$ e obgd.o [sic]

Paulo Prado".

O Jornal, Rio de Janeiro, 25 de dezembro de 1926, 2ª secção, p. 1.

\section{UMA HORA COM O SR. MANUEL BANDEIRA}

Manuel Bandeira, que hoje nos fala, foi sempre, na nossa literatura, um nome de vanguarda. E um dos que cantam. Esteve, desde cedo, resolutamente, com as ideias novas. O seu primeiro livro - "Cinza das horas", traindo embora influências [ilegível], trazia já, para a nossa literatura, com a sinceridade da sua irônica melancolia, uma nota de surpreendente novidade. Era diferente de tudo o que então aqui se publicava. Tinha mais alguma coisa do que palavras sonoras e rimas ricas... Depois, o "Carnaval" foi, para a nossa gente daquele tempo, uma surpresa grande. E foi, talvez, o livro que primeiro marcou, na nossa poesia, uma tentativa consciente de renovação. Quando apareceu, pôs interjeições de espanto nas fileiras disciplinadas da milícia parnasiana. Vinha com a força corajosa e bela dos voos livres. Era um grito lírico de libertação. Dizia-nos, com sinceridade e emoção, que era possível fazer poesia - sem rima e sem chave de ouro! Um escândalo... E, desta arte, o Sr. Manuel Bandeira, aparecendo em companhia de uma musa singular e melancólica, irônica e desabusada, veio dar o primeiro golpe sério no prestígio do parnasianismo. Depois, as poesias que ele continuou a publicar vinham confirmar a sua orientação: era um homem de vanguarda. 
Assim, até a sua última obra - "Poesias", que contém tudo o que ele fez e que nos dá, por assim dizer, um gráfico nítido da sua evolução espiritual. Agora, o Sr. Manuel Bandeira enfileirou-se com entusiasmo na "esquerda", se assim se pode dizer, do modernismo brasileiro. Está ao lado dos extremistas. Está "liderando" um dos vários grupos em que se cindiram os nossos modernos. E a sua atuação nesse posto, no meio dos meninos satélites que lhe gravitam em torno, tem sido brilhante.

Fomos ouvi-lo com intensa curiosidade. E com prazer. Sabíamos que ele nos poderia dizer coisas novas e interessantes. Procuramo-lo várias vezes. Da primeira, recusou. Que não queria meter-se nessas coisas. Insistimos. Prometeu. Por fim, uma noite destas, encontrando-o num café, aqui ao lado do O Jornal, arrancamos-lhe, quase com violência, uma entrevista. Conversamos longamente com ele. E não nos arrependemos. O Sr. Manuel Bandeira falou-nos com o brilho, a clareza e a graça de que possui o segredo.

\section{A entrevista, enfim!}

Quando lhe fizemos a nossa primeira pergunta, o Sr. Manuel Bandeira deu de ombros, tentando esquivar-se:

- Peregrino, me deixe quieto! Eu não sou modernista, nem literato, nem coisa nenhuma. Sou apenas um doente que de longe em longe vira poeta. Viro poeta quando estou estalando de raiva, — ou de ternura. Se você conhecesse a minha ignorância do que se chama o movimento moderno, tenho certeza que não me pediria entrevista.

Não tenho a menor vontade de falar sobre isso.

\section{Palavras de ironia}

Tomou um golinho de café. Deu uma boa gargalhada. Depois, sorrindo aquele seu velho sorriso cheio de dentes e cheio de ironia, começou a falar, num tom de pilhéria, como se estivesse brincando com as palavras...

- Depois que o ensaísta Sérgio Buarque de Holanda partiu pra invadir o Espirito Santo, eu deixei de receber a senha da vanguarda. Sérgio era o meu indicador de leituras, o meu revelador de Joyces e de Essenines, o meu mentor para a secção de literatura modernista. É o maior curioso de ideias que já apareceu no Brasil, e tem o instinto seguro do academismo que convém evitar.

Mas mudou logo de atitude. Ficou sério. E gravemente começou a falar. 


\section{Os vanguardistas brasileiros}

- Os vanguardistas brasileiros divergiram sensivelmente das vanguardas europeias. É visível em todos a vontade deliberada de fazer arte brasileira. Como não se sabe ainda definir o que é brasileiro (Brasileiro igual a português mais negro mais índio! Você mistura português com preto, no fim vai ver, sai um Machado de Assis, escrevendo feito Thackeray...), como em muitos pontos não se sabe bem o que é brasileiro, há muita contradição e incerteza nestes ensaios.

\section{A Arte brasileira existe}

- E a arte brasileira?

- Pra mim existe uma arte brasileira e não é d'agora. Alencar, Macedo, Manuel de Almeida fizeram romance brasileiro. Castro Alves, Casimiro, quase todos os romancistas, fizeram poesia brasileira. É verdade que parnasianos e simbolistas perderam todo contato com a realidade nacional. Mas isso não aconteceu só aqui. Não obstante na prosa de ficção fez-se também arte brasileira. Os romances de Aluísio, as comédias e revistas de Artur Azevedo, certas novelas de Coelho Netto, são arte brasileira. Igualmente o são o romance e o conto de Lima Barreto, as histórias de Afrânio Peixoto...

\section{O critério de Nacionalidade}

- E as características da arte brasileira?

- Ah, isso é outro caso!

Depois é preciso não apertar muito esse critério de nacionalidade em arte. Senão, mesmo nas outras literaturas... O que querem então pra arte brasileira?

\section{O movimento de agora}

— Fale-nos do movimento atual...

- Neste movimento d'agora há um aproveitamento artístico de elementos folclóricos tidos até aqui como inferiores, elementos que só apareciam pra dar cor local, pra enfeitar, como berenguendens baianos. Agora são assimilados. O que se quer é fazer deles carne e sangue substância mesma da arte. 


\section{A influência da cultura}

- Acha que a cultura nos prejudica?

- A cultura, é inegável, nos empobrece de brasilidade. Tudo que cai no brasileiro inculto, que é o brasileiro da gema, vira logo brasileiro. O maxixe não é tão caracteristicamente brasileiro? No entanto surgiu de uma adaptação de coisa estrangeira. Caiu no brasileiro e foi tão bem assimilado que hoje (e não faz muito tempo que apareceu) é um trabalho pra descobrir como foi como não foi.

\section{O que é preciso para fazer arte brasileira?}

O Sr. Manuel Bandeira parou, um instante. Sorriu por trás dos óculos. E prosseguiu tranquilamente:

- Pra fazer arte brasileira da mais gostosa é preciso ficar brasileiro como os meninos, como os incultos. A deformação começa quando principiamos a escrever. Em toda parte a língua literária é proximamente a língua das classes cultas. Aqui não. Observe a diferença entre a linguagem falada e a linguagem escrita de um brasileiro de boa sociedade. Dizem que a linguagem escrita é a correta. Mas todos nós receamos parecer pedantes empregando-a na conversação. Quem tem bom gosto prefere "errar".

O português, quer fale quer escreva, diz “quem m'o deu”. Qual é o brasileiro que tem coragem de falar assim? No entanto escreve... Eu sei que há sempre um meio de contornar a dificuldade. Mas é precisamente nesse contorno que reside a deformação do caráter. A poetas e escritores compete o dever de trabalhar artisticamente os brasileirismos até dar-lhe foros de linguagem literária.

- Muito obrigado.

- Não tem de quê. Porém, previna pelo seu jornal que eu não dou mais entrevista a ninguém!

O Jornal, Rio de Janeiro, 26 de dezembro de 1926, 2ª secção, p. 4.

\section{UMA HORA COM O SR. GUILHERME DE ALMEIDA}

Eis aqui a mais moderna das entrevistas. Uma carta-entrevista. Rápida. Surpreendente. Desconcertante. Interessantíssima na sua concisão. De quem? Do Sr. Guilherme de Almeida. Mandamos-lhe para São Paulo uma carta pedindo-lhe uma entrevista sobre o instante literário do Brasil. O poeta das Canções Gregas, após um longo hiato de silêncio, 
enviou-nos afinal a sua resposta - e que deliciosa resposta! Numa curiosa carta, desnorteante de humor e ironia, o Sr. Guilherme de Almeida falanos do modernismo. Mas fala como se estivesse aqui, diante de nós, afundado numa "maple" [sic], fumando cigarros do Cairo e pensando, displicente, nos progressos mirabolantes da sua "Cidade dificílima"... não chegou a nos dar uma hora de palestra. Mas condensou, em cinco minutos velozes e moderníssimos, um mundo de coisas interessantes, diabólicas, imprevistas, integralmente surpreendedoras. A entrevista-epistolar que o poeta da "Flauta que eu perdi" nos concedeu é, sobretudo, deliciosa, uma cintilante página de humorismo. De humorismos e ironia. Tendo falado já, uma vez, com convicção e gravidade, sobre o movimento moderno, historiando sua gênese e evolução no Brasil, o Sr. Guilherme de Almeida julgou agora ocioso reeditar suas ideias ao repetir suas palavras. E, em vez de falar, preferiu sorrir. Destarte, não falou — sorriu. Mandou-nos de São Paulo, não propriamente uma entrevista, mas um sorriso - um elegante sorriso de ironia e bom humor, claro, harmonioso, civilizado. Eis o que é esta entrevista - um sorriso. As suas ideias sobre o modernismo, afinal de contas, todos nós já as conhecíamos. Nem tínhamos o direito de ignorá-las. Ele as expusera, com um ar sério, diante do clássico copo de água passadista, na sua conferência do Centro Paulista, há de haver um mês, ou pouco mais. Para que repeti-las? Demais, o Sr. o Guilherme de Almeida tem tido, na vida, e na arte, esta preocupação constante: não repetir-se. A sua obra está aí para prová-lo. Não tem dois livros iguais. Da "Dança das horas" a "Raça", cada poema do Sr. Guilherme de Almeida é um milagre de novidade e invenção. Todos diferentes, dão-nos a impressão de que este Proteu lírico tem horror à repetição. Na obra do Sr. Guilherme de Almeida as musas se sucedem sempre novas e sempre belas. De resto, ele não precisava fazer a apologia do modernismo. Porquanto todos nós sabemos que o modernismo já acrescentou à sua bagagem literária três livros magníficos: "A frauta que eu perdi", "Meu" e "Raça”. Isso prova que ele está com o modernismo. Definitivamente.

Depois, o Sr. Guilherme de Almeida, mesmo antes de haver modernismo no Brasil, já era um poeta moderno - um poeta do seu tempo. "Messidor" não será, acaso, um livro de todos os tempos? Demais, "passadista" ou "futurista" - que importa! — o Sr. Guilherme de Almeida será sempre, e acima de tudo, essa coisa simples e rara — poeta. Ainda há pouco, a própria Academia Brasileira de Letras, indiferente à orientação renovadora do Sr. Guilherme de Almeida, teve a elegância de premiarlhe um livro de poemas - "Encantamentos". Mas o Sr. Guilherme de Almeida, ainda que a Academia não lhe houvesse coroado a sua obra, continuaria a ser, entre os poetas do Brasil, um poeta a quem a Glória sorriu, dadivosa e feliz. 
Porque este prestidigitador mágico de ritmos, cujo virtuosismo desconcerta e encanta, é uma pura alma lírica, que trouxe para a vida o destino dos pássaros - cantar...

E é curioso o que o Sr. Guilherme de Almeida nos conta na sua entrevista epistolar.

\section{Sobre o modernismo}

Diz a carta:

"Meu caro Peregrino - Você quis que eu dissesse qualquer coisa sobre o modernismo. Acho que ninguém no Brasil entende mais disso do que eu. Porque sempre fui considerado pelos outros poetas, meus amigos, um rapaz muito dado às coisas da moda. É impossível que você não tenha ainda ouvido falar no "poeta almofadinha", o "predileto das melindrosas", o "moço-armarinho", o "cantor dos tules, dos tafetás", etc., etc. Pois sou eu. Nessa matéria, não há dúvida, eu sou mesmo um autoridade. Sempre fui. Por exemplo: a primeira pessoa que, neste país, pôs em poesia a palavra "jazz-band", fui eu, em 1916. E agora, dez anos depois, o primeiro brasileiro que descobriu o nome da verdadeira flanela em que se talham as legítimas calças Oxford, também fui eu: chama-se: Pink-buff.

Ninguém, portanto, nesta terra atrasadona [sic] e morena, está mais indicado para responder com segurança a sua "enquete" do que eu.

Você quer saber o que penso do modernismo, do nosso instante literário, da nossa significação no pensamento atual de todo mundo.

Com franqueza, Peregrino, acho que não temos nem podermos ter, por nós mesmos, nada de perfeitamente moderno. Por enquanto, o Brasil ainda não inventou nada. Tudo quanto temos foi-nos trazido de fora. (Neste "fora" entra também a África com seus candomblés, seus cuscuzes, nas macumbas...[sic]). É preciso - se quisermos ser modernos - que tenhamos pelo menos um introdutor estrangeiro. Assim penso com muita convicção que deveríamos importar um "avanguardista" bem adiantado. Um daqueles rapazinhos da Rue Ravignan: 23 anos; cara engraçadinha e irresistível de jeune premier; buço; "badine"; terno bleu lavande; camisa bois de rose; chapéu vert amande; gravata cyclamen. Esse mocinho chegaria aqui e, numa escola qualquer, ensinar-nos-ia os grandes segredos da vida moderna, como, por exemplo, tomar o tube, falar em telefone de manivela e corneta; adotar lâmpadas elétricas Osram, andar muito de bicicleta com presilhas de aço para prender as calças embaixo, usar suspensório guyot, gostar das fitas Gaumont e dedicar-se à carreira de gigolo qui aspire à monter en grade... 
(Entre parêntesis, veja você, Peregrino, como só com o uso dessa porção de palavras entre aspas, esta carta já tomou um arzinho tão moderno).

É. Só assim o Brasil poderia ser mesmo moderno. E ter uma literatura, um pensamento novo. Original? - Para que ser original? A única coisa original, verdadeiramente útil e boa é o pecado...

Até logo, Peregrino! Rasgue esta carta e acredite sempre no seu Guilherme"

São Paulo, 19-XII-926.

O Jornal, Rio de Janeiro, 02 de janeiro de 1927, $2^{\text {a }}$ secção, p. 3.

\section{O MOVIMENTO INTELECTUAL EM SÃO PAULO}

O Sr. Menotti Del Picchia fala-nos sobre a chamada "revolução da Anta"

São Paulo vive uma permanente efervescência intelectual. Os escritores paulistas gostam de agitar ideia e fundar "escolas".

Daí a frequência com que em São Paulo surgem as "revoluções" literárias. Modernismo, futurismo, poesia pau-brasil, literatura verdeamarelo - tudo isso é São Paulo que inventa. Inventa e exporta. Agora, a última novidade literária que São Paulo nos manda é esta: "a revolução da Anta”.

- Que vem a ser isso? Interrogará o leitor curioso e espantado.

- Nós também não sabemos. Mas pedimos a vários escritores paulistas que nos explicassem os graves mistérios da nova "escola" e eles, todos, com convicção e solicitude, nos mandaram dizer suas ideias, as suas opiniões, os seus programas de ação intelectual. À frente do movimento está um romancista, o Sr. Plínio Salgado, que também nos falou. Abaixo aí vai a opinião do Sr. Menotti Del Picchia, poeta, cronista, conteur e romancista, que discute a nova "escola".

\section{A palavra de um Lupino}

- Quer saber de um Lupino a sua opinião sobre o caso da Anta? Tempestade num copo de água. Tudo acabou como antes no quartel de Abrantes.

Não houve cisão nem ameaças de dissidências na taba verdeamarela. É mania transportarem-se para os arraiais literários os surtos de furunculose sediciosa que pipoca por aí. O pessoal verde-amarelo é unido e disciplinado. É que é livre, sem peias nos processos de sua 
atuação, ligando-o apenas a um ideal de puro nacionalismo, de procura inquieta das verdades virginais da nossa terra.

\section{Como se conta história}

- Vou explicar. Eu, pelo Jornal do Commercio, edição paulista, há uns cinco anos, quis matar Peri. A tentativa de assassinato era dirigida contra um Peri maquilado, com tanga feita de penas de espanador e pele de malha cor de chocolate, cantando, em italiano, coisas do arco da velha nos palcos internacionais. Como propaganda de brasilidade, nem a febre amarela, nem a broca de café, nem as serpentes do Butantã não poderiam ser mais tristemente eficazes.

O caso arrepiou o nacionalismo lírico de alguns sentimentalões que conservavam a ilusão de que se faz propaganda indígena com camelots nus, caçados na Galeria Vitório, pelo Sr. Mochi. Estamos num instante pragmático e prático. Nada de imbecilidades...

Num comício democrático realizado solenemente no Cassino-teatro paulista, onde geralmente estreia o Ba-ta-clan - o Sr. Luís Aranha, torcendo o sentido do meu artigo, acusou-me de ter tentado assassinar em Peri alguma coisa mais que o cafumango-tenorino [sic], recheado de dós de peito como um peru com farofa. Defendi-me. Na defesa disse: não é o índio que eu quis matar. Quis alforriar o país do conceito internacional que de nós se faz, de sermos uma terra de botocudos. $\mathrm{O}$ Sr. Savage Landor descobriu jiboias nas árvores da Avenida Rio Branco. O Brasil não é isso. Ele tem uma alta civilização ocidental. Mamamos na loba capitolina, que aleitou os sagrados Dióscuros...

Rebentou novo motim. Em nome de Anta, o meu caro e luminoso Plínio Salgado, chamou-me à fala. Como era essa história de loba? Éramos ou não uma democracia americana, com uma reserva teogônica de totens pré-raciais capazes de fazer a fortuna de uma geração de teólogos? Como vê o negócio tomou um novo aspecto...

\section{A agitação}

- E houve polêmica cerrada por isso?

- Perfeitamente. Enchemos colunas de jornais como um jardim zoológico de totens. No fundo, eu não preconizava a Loba ilustre, de mamas divinas e criadeiras do gênio preclaro do Lácio. Eu e Plínio estávamos neste acordo: encontrar no passado histórico um símbolo que caracterizasse as forças cósmicas que deram e dão uma consciência 
autônoma etipicamenteamericana aos estratos imigratórios poligenéticos que aqui se plasmam na formação da futura Raça. Como vê, um alto e nobre pensamento. O Plínio bateu-se pelo tapir americano, a Anta das carreiras retas e precursora inconsciente da nossa rede rodoviária, tanque vivo e violento abrindo picadas à migração e ao nomadismo índio. Era um símbolo tentador e forte. Não pus dúvida em aceitá-lo. Demais, Plínio tem na sua prosa cerebral e rítmica, tal força de persuasão que, com espírito litúrgico e supersticioso me convencia de que a Anta é uma coisa tão respeitável para o Brasil como o Boi Ápis para os egípcios... Egípcios?

\section{O sentimento racionalista}

- Egípcios?

— Quer saber, porém, em tudo isso o que há de belo? É o sentimento altamente nacionalista que animou a discussão. Nós, do grupo verdeamarelo, mais do que nunca unido e coeso na sua cruzada, queremos reagir contra a refração espectral, contra o hiperidealismo de Rui, que com suas geniais utopias, quis vestir uma casaca num tupinambá. Queremos reagir contra o "meufanismo" [sic] verbal que acha o nosso meio físico tal maravilha, que colocou os brasileiros numa situação de indignos da sua própria terra. Queremos, no século prático, integrar nossa consciência de povo nas possibilidades físicas do meio e ver o homem em relação à terra que habita a ver o que esse homem, no nosso curto passado histórico, realizou dentro dessa terra.

Obteremos assim um novo idealismo, feito da posse material do Brasil, do contato mais íntimo do brasileiro com o chão pátrio, libertando-o das complicações decadentistas e inúteis da cultura ocidental, de que ele deve se alforriar definitivamente. Somos por uma arte nossa, direta, expressa por uma língua nossa sem acaudilhar-se a escolas, a fórmulas, a mestres das estranjas. Essa revolução mental terá repercussão em todos os campos da atividade brasileira.

$\mathrm{O}$ orgulho de sermos o que somos, porque somos o que podemos ser, isto é, o que nenhum outro povo realizaria no meio cósmico vasto e hostil como o nosso [sic]. Queremos o concurso de um processo de perquisição, pragmático, relativista na investigação das nossas verdades e dos nossos problemas. Queremos ser práticos e úteis, reconduzindo nosso pensamento a sua única realidade, que é a de se integrar no instante atual, modificado por processos mecânicos. Nossa poesia é feita da razão direta das nossas coisas e da nossa prosa é azul [sic] e rica 
em neologismos e de modismos verbais característicos da nossa gente. Perdemos o respeito pelo classicismo mumificador e misoneísta, diante do qual nunca conseguimos a nossa autonomia idiomática.

Tudo isso é, por convenção, Anta. Tudo isso é verde-amarelo...

\section{A Anta}

- É Anta?

- Anta... Porque como o confrade compreendeu, Anta é o símbolo necessário... Anta ou Caipora. Curupira ou Anhangá... Diz-se por aí, entre esses brasileo-modernista-franceses, que decalcam os figurinos mentais de Montmarte para assustarem caboclos, que nossa taba é feroz e antropófaga. Há tempos, sobre o assunto, recebi uma carta de Plínio Salgado. Dizia mais ou menos isto: "nossos ancestrais simbólicos provaram a carne episcopal e civilizada de Sardinha e a acharam gostosa... Devemos fazer festins diabólicos para assar, em grandes fogueiras de pau-brasil, os miolos literatos que os almofadinhas nacionais mandam buscar na França..." Aí fica o aviso da truculência da nossa taba. Agora até amanhã.

O Jornal, Rio de Janeiro, 20 de fevereiro de 1927, $3^{\underline{a}}$ secção, p. 1.

\section{A REVOLUÇÃO DA ANTA Plínio Salgado, em entrevista, a O Jornal}

Uma entrevista para O Jornal sobre a Anta e o antismo vem exatamente ao encontro de um meu desejo. Tenho mesmo interesse em falar ao Rio de Janeiro sobre este assunto, que reputo da mais alta relevância para o Brasil. À primeira vista, tudo parecerá aos intelectuais uma lírica patriotada. Parecerá que o movimento da Anta nenhuma relação terá com a nossa vida mental. E tais considerações serão bem naturais, uma vez que a nossa literatura perdeu, completamente, o senso das realidades.

\section{O Rio entenderá São Paulo?}

É preciso notar: observadas em conjunto, diferem profundamente as mentalidades das nossas duas capitais. Isso dificultará o entendimento a que deveremos chegar. Cercada de montanhas, olhando o mar, a cidade do Rio de Janeiro só entra em contato com a realidade brasileira através do morro da Favela e das piadas e trocadilhos mestiços largamente 
exportados pelas províncias. Ia-me esquecendo: há aí também a "macumba", como expressão racial... E o Dr. Jacarandá, e o cidadão Pingó, como expressão política, sistematizada desde a Saúde ao partidarismo municipal... Mas essa vida não é vivida pelos intelectuais que respiram ares da França. Pois tudo o mais, desde João VI que trouxe a cidade a bordo - tem um caráter de adaptação e de artificialismo.

Cidade burocrata e oficial, a obra da infiltração estrangeira, desde a Confederação dos Tamoios, tem sido aí tão dissimulada e insinuante, que não deu lugar a uma reação forte de nativismo. Fatalidade políticoadministrativa.

Aqui as massas imigratórias entram de supetão, com tal violência, que nos puseram de pé. No panorama dos arranha-céus, acordou a alma do povo "arrogante e sem respeito, perturbador da paz dos continentes", a que alude o cronista. Nos intervalos dos apitos das fábricas de São Paulo põe o ouvido no peito do sertão: é o ritmo da vida nacional.

As ressonâncias dessa vida chegaram aí no Rio com um acento político ou literário. Indiretamente. Essa cidade conhece as "consequências brasileiras", não as "causas brasileiras". O Brasil lhe parece como uma fachada misteriosa. Quando muito, será a visão panorâmica da poesia de Ronald.

Distinguem-se fundamentalmente as mentalidades do litoral e do interior. Pois, em relação ao país, uma se forma de fora para dentro, a outra de dentro para fora. Na capital da República, a disparidade com a província é agravada pelos hábitos burocratas e de sociedade, de oficialismo e contato forçado com as culturas e costumes exóticos. A inteligência requinta-se apurando a faculdade crítica, sobretudo o senso de comparação e de ecletismo, em detrimento da faculdade criadora. Possibilita-se a ironiazinha sutil das senilidades precoces, que é a raiva piedosa contra os que ainda sabem crer.

Floresce, absurdamente, no Brasil, um espírito como o de Machado de Assis. Ele não poderia sair senão do Rio, que respirava então Stendhal, como respira pelas últimas brochuras europeias. Na mais recente geração intelectual, incapaz de criar, como observa cruelmente Rodrigo de Andrade no largo e raivoso elogio que fez no O Jornal à intelectualidade paulista, há, mais do que o espírito de indecisão e angústia da civilização ocidental, um cheiro de senectude humanística, o bolor da sombria biblioteca do Sr. D’Astarak. Aquele sorriso cretino de Anatole diante da grandeza do inexplicável; aquela reação de que foi capaz diante da derrocada do seu país; e, principal[ilegível] mesentérica [sic] de Eça, unicamente, o esnobismo displicente e tecido de uma elegância espiritual nociva, que veio de Byron e Oscar Wilde e rebentou no almofadismo 
letrado dos países velhos, tudo isso influi aí no Rio para que poucos compreendam a nossa ingenuidade de crentes. Acredito, entretanto, que os jovens escritores do Rio não se magoarão com essa franqueza paulista de quem lhes quer muito bem. E, quando não concordem, pelo menos, levem estas coisas em conta de nossa imensa ingenuidade de provincianos...

\section{Aos vinte Estados do Brasil e ao Acre também}

Vou contar a história da Anta, não só ao Rio, mas às vinte províncias, nossas irmãs, que respiram, como nós o sol da América. Algumas bem saturadas de espírito clássico e latim com rapé, velhas igrejas lusitanas, velhas academias coimbrãs, sonetos \& Cia. Mas todas unidas por este mesmo sentimento brasileiro que as colocará de pé em luta contra a ditadura de cem anos dos pensadores e artistas estrangeiros. Contra nosso regime colonial.

\section{A voz do oeste}

A centelha do movimento da Anta faiscou uma noite, no decorrer de uma conversa entre mim, Alarico Silveira e Raul Bopp. A propósito de uma alusão que fiz a um artigo de Alarico (grande espírito e profundo conhecedor de coisas nossas), falou-nos ele da marcha bandeirante, no rumo do oeste, sugerindo as razões étnicas por que se encaminharam os paulistas naquela direção. Para ele, era uma saudade ancestral dos planaltos bolivianos, que o sangue índio implantou no sangue português, nas primeiras núpcias de raças, a que precisou João Ramalho. Os tupis tinham vindo daquela região.

\section{Che Tapya:}

Referindo-se à marcha pré-colombiana e à origem do nome dessa grande tribo, falou-nos do totem da raça, a anta ou o tapya - o maior mamífero da América e o único grande animal genuinamente americano do sul - totem largamente proclamado como tal pelos guerreiros, com os brados de "che tapya", que vieram atroando as brenhas, naquela procura épica e predestinada do Atlântico, por onde vinham, também numa procura épica de continentes, as caravelas lusitanas.

Ao passo que ouvimos interessadíssimos o notável paulista, eu, andava procurando a força que possibilitou a unidade nacional, a fim de 
usar dela como agente destruidor da nossa sobrevivência ao estrangeiro, ia sentido uma íntima revelação.

\section{A matemática dos sentidos raciais}

Nem os sistemas hidrográficos ou orográficos; nem a unidade do processo moral da formação brasileira; nem as contingências políticas, me eram mais sugestivas do que o próprio sangue Tupi, proveniente dos Ibiturunas (Andes), que eu via como um "denominador comum" das diferentes expressões humanas dos cruzamentos. Era bem verdade que não somente o Tupi entrou na formação brasileira, uma vez que havia outras tribos selvagens, que não eram tupis; mas o símbolo servia e podia abranger todas as famílias autóctones, e ser tomado como "senha" de um vigoroso movimento nativo. Pois, em toda parte, víamos o índio: Poty, no norte; Tibiriçá, no centro, e São Sepé, no sul.

\section{Escrúpulos da tribo Verdamarela}

Quando eu e Bopp falamos da Anta, nossos amigos verdamarelos puseram o bicho de quarentena. Tomaram-no, a princípio, como expressivo de uma função restritiva de preconceito racial. Espíritos irmanadados no mesmo desejo e na mesma fé, Menotti Del Picchia, Cassiano Ricardo, Motta Filho, Genolino Amado, Raul Bopp e eu, costumávamos discutir com o único intuito de chegarmos a um acordo. Na discussão tudo se esclarece. Não brigamos, mesmo quando usamos a violência no terreno das ideias. Espírito largo de tolerância. Acordo que estabelece desacordo. Até mesmo os que estão fora merecem o nosso respeito. Divergimos, por exemplo, em muitos pontos, do Mário de Andrade e votamos-lhe (de minha parte fervorosamente), uma grande admiração. Pregamos tacapadas [sic] no Oswald de Andrade, que nos agride também no seu rodapé do Jornal do Commercio, e, à noite, confraternizamos em palestras amigas na sala acolhedora do Correio Paulistano. Há tempos, Prudente de Moraes, neto, disse mal de um livro meu, e em correspondência que temos trocado, ele ficou sabendo que eu não faço questão de ser um grande escritor. Pois, se me interessa mais a humanidade do que os meus escritos, por que hei de amar mais a estes do que às minhas ideias? E, porque assim pensamos aqui, tivemos uma polêmica a respeito da Anta. Discutiu-se à beça. No fim, a Anta foi aceita, mas sem vencidos nem vencedores. 


\section{Tupyretama}

Aqui caberia um artigo de cinco colunas para mostrar a área geográfica abrangida pela influência tupi. E a área moral. E a área nos domínios da política, da estética e dos costumes, etc. Mas já estou comendo muito espaço. Deixo a sugestão.

\section{Censura}

Ocorre-me aqui Ratzel, um lindo pensamento de Greef e todo um livro de José Vasconcelos. Só mesmo num tratado ou num manifesto 21 tiros.

\section{Necessidade da tirania do sertão}

Para mim, o Facundo, de Sarmiento, tomava um novo sentido. Eu via o homem brotar da Terra e avançar para a cidade. Eu via a grande cortesã, visionada pelo profeta de Pathmos, invadida por uma manada de antas arrasadoras de cosmopolitismo, da crítica negativista, da falsidade das atitudes e, principalmente, dessa incapacidade de crer, remanescente de uma educação humanista e snob. Revoltava-me contra todos os passivos: desde os que se aferram às fórmulas velhas da filosofia, da política e da estética, até os que fazem arte nacional através de Marinetti e Max Jacob. Indigna-me a poesia turista de Cendrars; os vícios de Cocteau, Apollinaire, Morand; a macaqueação ultraísta [sic] e o estado de "dadá" de espírito; e, mais ainda, as contrafações de modernidade, em poetas com prejuízos tangíveis do parnasianismo e do simbolismo. Os gestos, mal vestidos de atualismo, de um ingurgitamento romântico a Rousseau; o romantismo sensorial dos impressionismos "torre de marfim": o preciosismo acadêmico geometrizando-se diferente no teorema cubista, submetido a um princípio e realizado sob preconceitos processuais. Em tudo, o predomínio de mil Lobões praxistas, desses Lobões cujo senso do direito nunca passou do rito e nos quais, por certo, a alta finalidade da estética jamais iria além da norma consagrada no "boulevard". Já não quero falar do panorama político-social, do qual tratarei mais tarde. Mas foi assim conjecturando que o meu [ilegível] "nhengaçu” que desencadeou a discussão que se tornou base do acordo em que hoje estamos em São Paulo de desenvolver uma ação nova no Brasil. Interpretando-se com novo sentido Os Sertões, de Euclides, e o Facundo de Sarmiento. 


\section{Porque o Índio}

Escrevi, em um dos meus artigos, o seguinte:

"Eu ainda não vi o Brasil vivo e pensante: o que eu tenho visto é uma Europa viva e pensante vivendo e pensando o que nós chamamos de nossa vida e o nosso pensamento. Mas, há uma outra vida e um outro pensamento, que devemos revelar ao mundo; e esse é o Brasil vivo pensante que dorme pesadamente sobre uma montanha de livros e que precisamos despertar porque se aproxima o momento da sua fala sem haver consciência, precisamos libertar-nos de todas as contribuições de consciência alheia. Como símbolo da ação que temos de desenvolver, tomamos o totem de uma raça que, objetivamente, desapareceu, porém é uma incontestável realidade na nossa formação étnica. E não se confunda formação étnica com formação nacional, que é outra coisa decorrente desse fator e de outros ainda. E se nos perguntarem porque tomamos o índio, diremos que pela sua virgindade a nos ensinar, constantemente que, não tendo nós ainda pensado pelas nossas cabeças, podemos fazêlo sem compromissos com as velhas civilizações. Responderemos ainda que, pela nenhuma contribuição cultural e civilizadora que ele nos trouxe à formação nacional, pode a nação dizer-se sua descendente sem submissão histórica, até sem gratidão, o que a faz mais livre. E foi justamente esse senso de individualismo nacional que ensinou as clãs primitivas a se dizerem descendentes de bichos: para que pudessem fazer sua eclosão com uma força de liberdade selvagem."

\section{A civilização diferente}

E depois declarei:

"Nós queremos criar uma nova mentalidade, não desenvolvida exclusivamente sob o influxo da cultura universal, mas respirando nesta, com raízes na terra. E quando digo "terra", quero abranger "meio cósmico e étnico".

Não sei ainda "como será" a cultura americana. Aos gênios do futuro compete responder-nos a angustiada pergunta. Não podendo alcançálos, queremos comovidamente anunciá-los ao Mundo.”

\section{Não se trata de indianismo}

Escrevi esta frase 17 vezes em cinco artigos. Mas escrevo ainda mais uma vez. Não se trata de indianismo. 
O que queremos é um Brasil masculino, que tenha a iniciativa dos atos fecundantes. Pois há povos masculinos, que fecundam, e povos femininos, que são fecundados. Como há espíritos femininos, que se emprenham pelo ouvido. Queremos, pois, um Brasil brasileiro. Não faço isso por patriotismo, mas por humanidade. Pois vejo que a civilização ocidental europeia faliu. Já nada se espera dela. Temos (e quando falo temos quero abranger vários séculos futuros), temos que criar uma civilização em que talvez o gênero humano seja mais feliz. Isso parece pilhéria, aos espíritos (como a maior parte dos intelectuais brasileiros), que esperam sempre o resultado do que se dá em outros países. Mas creio firmemente que não o é. Ponho uma grande fé na "raça cósmica” de que fala José Vasconcelos. Ela poderá dizer a última palavra.

Voltemos à sabedoria da infância. Por que nascermos velhos? A Europa é uma velha caduca, nós somos um povo criança. Declaremos à velha que somos filho do índio como o índio era da anta. E nada temos a ver com gente estranha. O movimento da Anta é de ação. Ação verdamarela de independência. Sentir diretamente, dizer diretamente. Perder essa noção do ridículo, ministrada por estrangeiros e inimigos, essa noção que nos fez perder o brio nacional. Não mais dizermos que somos latinos. Isso é política que nos prende eternamente à Europa. E onde já se viu caboclo e mulato latino? Acabemos com esse respeito supersticioso pelas coisas que vêm de fora. Sejamos brasileiros para sermos dignos da Humanidade.

O Jornal, Rio de Janeiro, 13 de março de 1927, $2^{\underline{a}}$ secção, p. 7.

\section{REFERÊNCIAS BIBLIOGRÁFICAS}

Acervos Consultados:

CEDAE - IEL - UNICAMP (Centro de documentação cultural Alexandre Eulalio do Instituto de Estudos da Linguagem da Universidade Estadual de Campinas).

AEL - IFCH - UNICAMP (Arquivo Edgard Leuenroth do Instituto de Filosofia e Ciências Humanas da Universidade Estadual de Campinas).

Hemeroteca Digital Brasileira / Biblioteca Nacional Digital Brasil: http:// hemerotecadigital.bn.br/

Periódicos Consultados:

O Jornal (1926 - 1927)

O Paiz (1927)

Artigos e Livros:

A PINTURA moderna vista por uma artista moderníssima. O Jornal, Rio de Janeiro, 17 ago. 1926, p. 2. Disponível em: <http://memoria.bn.br/pdf2/110523/ per110523 1926 02356.pdf >. Acesso em: 15 set. 2012. 
BARROS, Jaime de. Como pensam e sentem os homens moços do Brasil. O Paiz, Rio de Janeiro, 2 jul. 1926, p. 1. Disponível em: <http://memoria.bn.br/pdf/178691/ per178691 1926 15230.pdf >. Acesso em: 13 set. 2012.

BROCA, Brito. Documentos de uma época. A Gazeta, 6 set. 1958.

PEREGRINO JÚNIOR. O movimento intelectual em São Paulo. O Sr. Menotti Del Picchia fala-nos sobre a chamada "revolução da Anta". O Jornal, Rio de Janeiro, 20 fev. 1927, $2^{\underline{a}}$ secção, p. 1. Disponível em: <http://memoria.bn.br/pdf2/110523/ per110523_1926_02517.pdf>. Acesso em: 15 set. 2012.

. O Movimento Modernista. Rio de Janeiro: Ministério da Educação e Cultura. [1954]. - Revolução da Anta. Plínio Salgado, em entrevista, a O Jornal. O Jornal, Rio de Janeiro, 13 mar. 1927, $3^{\text {a }}$ secção, p. 7. Disponível em: <http://memoria.bn.br/ pdf2/110523/per110523_1926_02535.pdf >. Acesso em: 15 set. 2012.

. Uma hora com o Sr. Guilherme de Almeida. O Jornal, Rio de Janeiro, 2 jan. 1927, 2 $2^{\underline{a}}$ secção, p. 3. Disponível em: <http://memoria.bn.br/pdf2/110523/ per110523 1926 02475.pdf >. Acesso em: 15 set. 2012.

. Uma hora com o Sr. Manuel Bandeira. OJornal, Rio de Janeiro, 26 dez. 1926, 2ª secção, p. 4. Disponível em: <http://memoria.bn.br/pdf2/110523/per110523 192602469. pdf>. Acesso em: 15 set. 2012.

. Uma hora com o Sr. Paulo Prado. O Jornal, Rio de Janeiro, 25 dez. 1926, 2ª secção, p. 1. Disponível em: <http://memoria.bn.br/pdf2/110523/per110523_1926_02468. pdf>. Acesso em: 15 set. 2012.

. Uma hora com o Sr. Renato de Almeida. O Jornal, Rio de Janeiro, 28 nov. 1926, 2 $2^{\underline{a}}$ secção, p. 5. Disponível em: <http://memoria.bn.br/pdf2/110523/ per110523_1926_02445.pdf>. Acesso em: 15 set. 2012.

. Uma hora com o Sr. Ronald de Carvalho. O Jornal, Rio de Janeiro, 31 out. 1926, 2a $2^{\underline{a}}$ secção, p. 4. Disponível em: <http://memoria.bn.br/pdf2/110523/ per110523 1926 02421.pdf >. Acesso em: 15 set. 2012. 
